\title{
The Experiences of Female Principals in the Gauteng Province
}

\author{
Michèle Schmidtt, ${ }^{1, *}$ Raj Mestry ${ }^{2, *}$ \\ ${ }^{1}$ Faculty of Education: Simon Fraser University, British Columbia \\ ${ }^{2}$ Department of Education Leadership and Management: University of Johannesburg \\ *Corresponding author: mschmidt@sfu.ca, rajm@uj.ac.za
}

Received May 12, 2015; Revised May 27, 2015; Accepted June 05, 2015

\begin{abstract}
Gender bias towards South African female principals remains a problem and compelling issue. The South African Constitution addresses gender equality, yet women still do not experience equal rights in practice. Using a theory of intersectionality, this study highlights the experiences of three Coloured South African female principals and how they negotiated various challenges and obstacles that they were faced with in their day-to-day running of their schools. Using openended questionnaires and semi-structured interviews, it was found that the principals' strong upbringing and family support, and sound educational background paved the way for them to become effective leaders despite numerous challenges. The results provide a significant contribution to the small body of literature employing intersectionality theory as well as the literature around female principals' experiences in South Africa. Sub-intersectional themes emerged providing a deeper understanding of their experiences, challenges and successes. These contextual themes examine the impact of social networks that include family and friends as well as professionally and types of discrimination and stereotyping on their experiences as principals.
\end{abstract}

Keywords: gender, intersectionality theory, principalship, social capital, women leadership

Cite This Article: Michèle Schmidt, and Raj Mestry, "The Experiences of Female Principals in the Gauteng Province.” American Journal of Educational Research, vol. 3, no. 7 (2015): 813-821. doi: 10.12691/education-3-7-4.

\section{Introduction}

Scholars [3] cite examples of gender bias among female leaders in Western schools; however, in South Africa, the issue is more of a pandemic. South African researchers [24] found that many South African female principals face triple oppression, namely race, class and gender. Although the Constitution [30] addresses gender equality, women in the education sector still do not experience equal rights in practice. The predominance of males in educational leadership posts continues to define the South African culture [10]. Historically, South African women dominated the teaching profession [17], yet there remains a dearth of women in leadership positions. For example, in the Johannesburg Central district of the Gauteng Province where this study was located, the most current statistics (2014) from the Gauteng Department of Education (A Chanee, pers. comm.) revealed that 201 males and 84 females currently hold principal posts.

South Africa continues to promulgate the government's transformation agenda with little evidence as to its effectiveness regarding the enhancement of gender equality or an open plan of action to meet democratic and transformational imperatives [27]. Despite the postApartheid government's 'gender equality' initiatives such as appointing more women in senior management and leadership positions [17,26], activists remain ambivalent regarding their impact.
The purpose of this paper is to focus on a more contemporary understanding of how female principals manage their schools, that is, negotiating challenges and obstacles that confront them in their daily encounters. Being mindful of the socio-political context within which female principals' work and understanding these conditions is essential to comprehending their experiences. While an exploratory study such as this may seem less than relevant to the field of women leadership since critics might claim that this approach is mere repetition and confirmation of prior studies, the originality of this paper lies in its application to South Africa, Coloured female principals, and an opportunity to reflect on the participants' lived experiences.

Leadership in South Africa differs from Western leadership models [27] by virtue of a complex and layered history. Postcolonial feminists are critical of Western forms of feminism and argue that cultures impacted by colonialism are different and should be treated as such. Any feminist approach must be mindful of women's unique contexts [25]. Female principals in developing or first world countries who are struggling with their leadership roles will benefit from the findings of this study. Therefore, this study contributes to a valuable but small body of literature related to an international or global context. In a country attempting to chart transformational territory in the field of leadership and learning, this study becomes relevant and meaningful to female principals in other regions of Africa and in other countries around the globe. 


\section{History}

\subsection{Apartheid}

The history, culture, identity and politics of Coloured people in South Africa remains complex and rooted in a distinct divide in their identity during and after apartheid . Considered a 'mixed race,' often known as Coloureds, they are descendants of intermarriage with White settlers, African natives and Asian slaves. Occupations as White people's servants, laborers on farms, and skilled trades people (masons; engineers; seamstresses; diamond polishers; and tailors) were common. Coloureds spoke both English and Afrikans and practiced Christianity and Catholicism. There was always a close relationship between Whites and Coloureds despite the fact that Coloureds were never fully integrated into White society. For most Coloured people, the desire to assimilate with White people was grounded in feelings of superiority over their Black counterparts and their desire to attain the same economic status and education as White people . Such outlooks led to a 'caste' system amongst Coloured people often due to colour gradation, and a lack of cohesion, unity and a debilitating identity crisis. Coloured people located themselves in society on a continuum of either: 1) aspiring to be accepted as part of the White society; 2) as a separate group, threatened by Black people; 3) as a separate group, but in solidarity with Black people and other oppressed peoples; or, 4) as part of the Black population. Often charged as being apathetic about politics, scholars posit that this was due to their trust in White politicians. The political savvy of White politicians involved promising incentives and jobs and education to coerce Coloureds to align with their political agendas and to encourage them to vote for their parties. Jobs and education were, however, limited to Coloureds due to their poor education and their lack of skills limiting their access to jobs. It became clear that the foundation of apartheid was based on segregation; therefore, efforts of assimilation were impossible since any unification defied the very foundation of apartheid.

\subsection{Post-Apartheid}

In post-apartheid South Africa, or what is known as the "new South Africa," there are almost four million (10\% of the population) Coloureds. Coloured identity shifted dramatically with an all Black government in power. The Coloureds experienced discrimination that was more damaging than what they experienced with their White political allies during apartheid. When once they felt superior over the Blacks, they now faced chauvinism. Having always enjoyed a position of relative privilege, they experienced marginality, betrayal by former supporters of the anti-apartheid movement, and loss of status [1].

Most of South Africa's Coloreds live in urban and rural areas around Cape Town. Some migrated to major centers such as Johannesburg, Pretoria, Port Elizabeth, East London, and Durban and in neighboring nations such as Namibia and Zimbabwe. During apartheid, Coloureds were forcibly moved to segregated regions. This meant leaving their church, community and friends. While Coloureds are now able to choose where they would like to live, options remain limited due to their economic situation. Living options range from farmworker communities on commercial farmland; mission stations; Coloured reservations; segregation townships; the Cape metropolitan area; the urban regions; and segregated residential areas. Two of the women, (Matilda and Candice), live in the same Coloured segregated township. In the past two decades, Coloureds began to embrace their identity after rejecting it during apartheid. Their concern of an African majority rule, feelings of being marginalised by a Black government, their desire to mitigate negative stereotypes, and fostering a renewed interest in political agendas, fueled Coloured assertiveness in the new South Africa.

\section{Theoretical Tools}

This paper takes into consideration the intersections of gender, class and race that confine and constrain the experiences of principals. We employed the theory of intersectionality to investigate the structural and individual contexts within which these women work. Intersectionality theory captures aspects of history that contribute to the damaging and entrenched patriarchy in their work.

Intersectionality theory as a form of intellectual feminist analysis theorises identity and oppression [9]. Also known as interlocking systemsof oppression, researchers are able to explore the ways that gender, race, and class intersect to create inequality. Collins [9] offers a theoretical framework with which to explore how intersectionality reveals women's work as an intellectual and activist activity. The theory serves a number of purposes, most prominently, as being a catalyst for change, addressing equity issues in the workplace, and promoting social justice. In this way, the women's expertise is honoured and space is provided for their voice outside of the Western mainstream. As a theory of interlocking systems of oppression, intersectionality claims that systems of race, class and gender shape women's experience [9]. In order to understand women's different lived experiences and social realities in their posts as principals, intersectionality theory provides the flexibility to work within a matrix of domination to help us unpack the complex layers of history and social systems of oppression [9].

The idea of using intersectionality as an analytical lens in this study enables researchers to examine the situated woman in the centre of domination. While located in these spaces, the interpersonal domain influences women's daily interactions with others in their personal and work relationships. Transformation occurs when women engage in critical reflection of their context. Collins stresses that it is a woman's responsibility to recognize her own victimisation - to "see...how her own thoughts and actions uphold someone else's subordination" [9]. Structure and disciplinary domains are typically resistant to change while the domains of interpersonal relationships located in the interstices of structure can be negotiated. It is in these spaces where women can find cracks and fissures with which to recast and resist hegemony and thus consider individual agency. "Bringing these domains together creates a more dynamic system, wherein the 
priorities of black feminist thought and understandings around the contradictions of suffering can empower their belief in social justice causes" [9]. Within our theory of intersectionality, we seek to understand the women's ability to negotiate the spaces and fissures within structures as recommended by Collins [9].

\section{Research Methodology}

A qualitative research methodology brought to the forefront the varied experiences of women principals. Open-endedqualitative questionnaires followed by individual interviews were the main data-gathering tools used to explore the uniquely contextualised nature of women principals' experiences. It also allowed us to follow up on information in the questionnaires to investigate further for clarification and elaboration of their initial responses.

Our sample included three female principals located in the Johannesburg Central District of the Gauteng Province, one of nine provinces in South Africa. A purposeful sampling method was used because the district was in proximity of one of the researcher's place of employment. The criteria for selection of our participants were that the females were principals in rural and urban secondary and primary schools for at least two years and participated in an International-local University's Leadership for Learning Intervention Programme.

The data were analysed for content, broadly using Tesch's method of open coding [11] in order to identify themes. By reducing data semantically a type of analysis developed in grounded theory research [6]. Empirical information was broken down into themes, clustered and coded using a process of axial coding to find the essence of the information. Ultimately the collated information allowed salient themes to emerge providing us with subintersectionality domains and their impact on the women's work that include social networks and discrimination.

The study adhered to strict ethical requirements. Consent was obtained from the Ethics Committee of the University, the Gauteng Department of Education and the principals of the chosen schools. Participants were ensured of their anonymity and were made aware that they could withdraw from the research at any time. To ensure confidentiality no personal information would be revealed without the participants' consent.

We used Lincoln and Guba's [23] norms of trustworthiness, namely, credibility, transferability, dependability and confirmability [29]. Prolonged engagement, triangulation, member checks and peer debriefing were used to promote confidence that the researchers had accurately recorded the phenomena under investigation (credibility). Transferability was addressed through purposive sampling and through the provision of rich descriptions, which allowed the researchers to have a proper understanding of the phenomenon under investigation. Before the initial interviews took place, the researchers made contact with each participant telephonically to establish a relationship of trust between them (prolonged engagement). Regular checks were done with the participants to ensure the accuracy of data collection (member checks), that is, transcription of interviews was given to each participant to verify [29].

\section{Analysis and Findings}

Theprincipals who worked at three different primary schools shall be known as Matilda, Candice and Emma.

In our analysis of the three women's experiences, we were able to identify themes by asking questions such as: How does a female principal challenge the patriarchal society? How does the family and how do social networks facilitate or inhibit the success of these principals? How do the principals negotiate the challenges they face in their workplace? What are the mitigating intersectional factors? How do the participants' biographies and demographics contextualize their experiences? How does a woman's class impact her success? As researchers, we sought the intersections within which each woman located herself and the identities that emerged from these intersections. Elements of social networks, family and community, and discrimination were unveiled and were helpful in making sense of the women's experiences.

\section{Family, Community and Professional Networks}

When we asked the women about their educational background, all the women had a Teachers' Diploma, the Advanced Certificate in Education (ACE) and either a Masters in Education or were currently working towards that degree.

When asked about their family background, Matilda said both her parents were Coloured and originally from Eldorado Park. She was born in Johannesburg, but the family moved back to Eldorado Park when she was a youth. She now lives in Roodepoort in Gauteng. She was the eldest daughter with two male siblings. She explained "we were not rich but lived an average lifestyle. I come from a very strict Christian family. My father was a teacher and later became a pastor. My mother was a very hardworking seamstress and took pride in her work. As the only daughter my father was very protective over a good disciplinarian and me. The values my parents instilled within me made me the successful person I am today."

Candice relayed that she was "born and raised in Protea, Johannesburg...brought up in a very strict Catholic home with [her] parents, two brothers and one sister...[and she had] two sons aged 21 and 18." She continued by saying: "My parents were hardworking and always strived to give us the best. My brothers and I are very close and we live close to each other. They are very protective over me even though I am the eldest." Her "father owned a dry cleaning business and [her] mother,...was a house wife." Between them, they had a Grade 10 and Grade 12 education. Her mother was a seamstress before marrying while her father apprenticed as a cabinetmaker.

Emma described having " $a$ very strict, disciplined upbringing.... My dad was a disciplinarian [while] my mom was the patient one and very supportive... "My mom is a Hindu, my dad is a Venda [Black] man from Louis Trichardt in Limpopo." Her father "was a Warehouse Manager and [her] mom worked at a diamond factory as a polisher....After a few years she got ill and had to stay 
home." She also had three younger brothers. She remarked "education was a priority in our family."

When we asked each principal why they became an educator, Matilda believed she was a born leader: "I believe I have that special gift to work with children...[I] realized what an impact I had on the learners. I could motivate so many of them...My strong background in leadership and management urged me to opt for the position as a principal and I always believed that I was a born leader."

Candice flourished when she entered college and entered the principalship by accident since she had no career plans before college. She taught at Suikerbos Primary Schoolas a post level one teacher. When the principal resigned, she became acting principal, and when the position was posted, she applied and was hired as a principal. She proudly shared: "I was the first non-white person to be appointed in the South of Johannesburg at a ModelC school. I always say I was at the right place at the right time. I was the youngest principal in the district... To me this was a great achievement....The school has grown from 320 children to 1197 to date."

Emma was driven to set planned five year goals always leading to a promotion of some kind: "Growing up I was always in a leadership position. I always loved a challenge. When I entered the teaching profession I set goals for myself. After being a post level foundation phase teacher for 11 years I believed that I was ready for an HOD post and every five years after that I applied for the next level promotional post and was successful so I've climbed the ranks as teacher; Head of Department (HOD); Deputy Principal and now currently Principal."

When we asked the women what expectations their parents had for their careers and what expectations they had for themselves, Matilda's father encouraged her to have a plan A and a plan B when thinking about her career. She explained that "as an educator himself, [he] always pushed us to get good grades and always instilled in us how important education is and said education does not end at matric. He always said that it was very important to get a diploma or a degree and that you must always have a plan A and plan B in life. He encouraged me to go into a direction where I could be assured of a stable job at the end of the day, like teaching. This was made possible by my parents who paid for my studies." As for expectations for herself, she was ambivalent about teaching since she originally wanted to be a fashion designer but she also wanted to please her father: "My father was not too happy for me to go study fashion designing in Durban during those years. I then opted for my $2^{\text {nd }}$ option teaching... I wanted a stable job and one that would sustain me through the future."

Candice explained: "My father was very conservative. He was just interested in what my brothers would do. I think they [my parents] were just happy that I went to work in the bank. When I decided to go to Rand College of Education, they were very supportive." As for her own expectations for herself, Candice admitted that she had none: "Thinking back I had no expectations for myself. I never had to work hard for anything but when I put my mind to something I worked hard and made a success of it."

As for Emma, she explained "My parents always wanted us as children to be successful. They did not have any specific careers that they wanted us to follow. They supported our choices. They wanted us to get Tertiary education, which we all achieved as their children. As for having expectations of herself, she said all she wanted was "to be successful nothing more, nothing less."

Matilda felt fortunate that she was positively influenced by her "parents, teachers and pastor." She commented that "some of [her] friends had a negative influence on [her] life and she decided to cut out the negative influences and follow the positive ones." She had supportive colleagues who "saw [her] strong leadership ability and encouraged [her] to apply for higher positions." She said, "When I ended up at the district I was already in the first month appointed as the coordinator of a group of 15 people. After a year my supervisor put me in a developmental program as a senior educational specialist. Thereafter I applied for the principalship position.” Similarly, Candice was grateful for the support of her parents, three uncles, her two sons, and two teachers. As for negative influences, she said, "I... learned at a very young age that you learn from them [negative people] and distance yourself from them. I have also learned that you do not carry baggage with you so I forgive and move on. In the professional realm she was encouraged by the School Governing Body (SGB) and her Institutional District Support Officer (IDSO). Emma's positive influences were her "husband, parents and... previous principal [who] encouraged [her] to become a principal." On the other hand she said. "My friends in secondary school were my negative influences to a certain extent".

When asked to provide examples of successes, failures and challenges the women experienced in their post as a principal, Matilda described having success with her studies and had learned from her colleagues of different backgrounds. She admitted, however, to being impatient and wanting to be unique. Interestingly she viewed these as failures: "One of my biggest failure is impatience. I always want something to be done immediately as I put too much hay on my fork and struggle to get to everything. My limitations are when I'm bogged down to follow one pattern and when people want to take away my individuality. I like to be unique in what I do and do not want to follow in others' footsteps. I'm a leader not a follower."

Candice's success was updating an old Afrikaans school and modifying it to its present state with few resources. She described the situation by saying that "The previous Afrikaans school took everything the school had leaving us with no classroom furniture, old books, and two old, outdated computers. They took the school bus as well as the carport. We had to beg and beg and borrow furniture from schools in Eldorado Park and Soweto....Th[e] school [became] one of the few schools with a well-structured and well-established computer room... So everything that the school has now, this staff and I have worked for, through fund raising and donations. She cited her biggest failure as being too lenient with her staff and avoiding conflict.

Emma proudly said that she introduced a math program, which improved students' math skills. The biggest challenges at the school are poverty, the negative mindset of the community and the low maturity levels of her staff. 


\section{The Schools}

Matilda was 48 years old and had been teaching for 24 years, serving as a principal for the last three years. She was posted at Tuliso Primary School located in a disadvantaged community that was riddled with serious socio-economic problems. The school, situated in an impoverished township, was very large with a black student population of over 1500. Overcrowding was a major problem as was the deteriorating infrastructure of the school. Safety was a concern since there were gangrelated activities in the area and the school had two burglaries in recent years.

Candice was 49 years old, a teacher for 12 years and principal for 14 years. She worked at Suikerbos Primary School, another large school in the district. The student population consisted of 1194 students with the largest black indigent student population in South Africa (i.e. foreign, refugee, asylum seeking) with students coming from all over the continent and also from other provinces in South Africa. Candice explained that there were many cases of neglect among the children.

Emma also lived in the same segregated community as Matilda. She grew up in a working class/low-middle class section of the township, which could be attributed to her parents' blue-collar occupations since her father was a warehouse manager and her mother, a diamond polisher in a diamond factory. Emma was 45 years old, had been a teacher for 22 years and now a principal for two years. She taught at Eldies Primary School in Eldorado Park, a township in which she also lived. Of the 1174 students, $95 \%$ lived within walking distance of the school. Ninety percent of the students were coloured, and ten percent were black.

What is immediately striking is that the women's socioeconomic status (SES) and social networks varied from working class, and low to high middle class. Class often impacts networking opportunities, advancement in education, and cultural knowledge in different ways depending on the women's SES [4]. Not surprising, with Matilda's higher socio-economic background, her social network of positive supporters was broader than the other women's. Candice and Emma's social networks, particularly their professional networks, were not as broad. Due to the variation in socio-economic levels amongst the women, there were subtle differences in the way the women perceived their leadership experiences. For example, Matilda believed she was a born leader; Candice flourished when she entered college but by and large thought that her principalship was by accident since she had no career aspirations nor did her family have any aspirations for her since the focus was on her brothers' careers. Emma, perhaps an anomaly, was driven by selfimposed goals that led to her planned promotions.

Of all the women, Candice overtly expressed uncertainty about her self-worth as a principal. She cited many examples that contributed to these feelings and experienced great stress at work and home, and as a result, thought of resigning. Cubillo and Brown [14] found that South African women struggle with personal issues such as professional experiences, conflict, emotions, aspirations, ambitions, and confidence, particularly impacted by class. On the other hand, Matilda and Emma consistently displayed high levels of self-esteem. Matilda felt challenged by being a coloured principal in an all-black school and described how black teachers challenged her leadership. However, when they realized that Matilda was confident and respectful towards them, they respected her. In addition, male black teachers became protective of her since the school was located in an unsafe part of the township. Matilda's wider social network was significant. When translated as social capital how much or how little capital the women have impacts the benefits or limitations women gain (or not) in the form of social networks, selfesteem, ambition, success, career advancement, agency, and the ability to negotiate challenges individually or with the help of others or despite others [4]. Here we see an example of a principal from a high-middle class background displaying high self-esteem, a broad social network, ambitious, agency and the ability to navigate discrimination with the help of others. There are important connections among self-esteem, measures of success, and social capital related to family, relationships, and friendships [4]. Therefore, Matilda's class manifested quite differently from Candice for example, as Matilda's wider social network assisted in her ability to lead in a positive manner despite adversity. She also refused to be intimidated by acts of discrimination and had the ability to network with her black male colleagues.

Coming from a working class background and living in a household of brothers, Candice did not have any career expectations for herself prior to entering the education field. She seemed lost in terms to what she wanted to devote her life. She worked in a bank but found that boring. She seemed to become a teacher by accident with no overt encouragement from her family as their prime interest was in her brothers' careers; her social network was also small with little if any support in her career decisions. The focus on education is a courageous one on the part of Candice particularly since she selected this vocation herself. Fortunately, her family supported the decision. However, once she became principal, they were proud of her and assisted with her tuition. Emma also hailed from a low economic status. Despite this however, she displayed a strong drive to be a principal. She purposely set goals for herself so that she applied for a promotion every five years until she achieved her goal but became disenchanted with the position once she attained the principalship. She discovered that not all her colleagues were supportive of her leadership; black staff transferred to other schools and female teachers made it known that they preferred a male principal. She discovered how lonely it was being a principal. She made it a point neither to trust anyone nor to compromise her principles as an individual. She seemed to flounder emotionally and felt isolated in her role even with her 14 years of experience. On the other hand, Matilda, having grown up in a middle-class environment, flourished and established numerous school and community networks in only three years.

\section{Discrimination}

Of all the women, Matilda firmly believed in not becoming a victim of her circumstances and that with hard work and strong values, women can and should earn respect. The women seemed to negotiate the 
discrimination they faced in different ways. In attempting to draw a relationship between class and discrimination, studies posit the contradictions that reveal positive, null, or inverse relationships. Yet, these authors point out that "the argument that the individual's social status should be related to his personal feeling of worth seems so selfevident as to represent a virtual triviality” . To cope with the many challenges of discrimination, Emma seemed to win the trust of the black male principal colleagues and aligned herself with their support. The support of the black male principals seemed to divertthreats she received from the black female principals in other schools. At the time of the study, Emma seemed frustrated, stressed and worn down by her post as a principal and decided to resign after only two years. Gupton and Slick [20] urge women not to reinforce the glass ceiling by not believing in themselves, and their potential to do well in leadership positions. Candice and Emma, on the other hand, had succumbed to negative experiences in their role as principals by feeling unworthy and alone. They both came from low SES backgrounds while Matilda grew up in a supportive middle-class environment. Had their low SES influenced their self-esteem? While the answer to this question is difficult to discern, both Emma and Candice hail from low SES and interestingly, both women were unhappy with negative feelings. In fact, Emma, Candice and Matilda all planned to resign.

Now that Matilda had been a principal for some time, we asked what impact her one of the following or more dimensions of class, race and gender had on her experience as a principal. She explained that because her school's student and teacher population was black, she as a female coloured principal "was welcomed with a lot of skepticism and the parents and teachers wondered how I would cope with the language and community issues." She was pleasantly surprised when, "I received a lot of respect...[particularly] with the little Sotho I spoke.” She admitted, "[black]teachers tried to challenge me but were met with very wise and knowledgeable answers [from me]. A lot of perceptions have changed since then. [Black] male teachers seemed very protective over me and always made me aware of how unsafe the community is."

Candice believed that "barriers women face in reaching management and leadership positions are constructed largely from stereotypes of the female roles in society, sexist institutional cultures and inadequate organizational support. I had a difficult start as a principal. Old Afrikaaner male principals and old English speaking white female principals surrounded me. I had no support from the schools in the area. I had to work harder to prove myself as well as to succeed because they were all watching." A negative experience she had was when she learned that a colleague "on the shortlisting and interviewing panel refused to agree to me being recommended for the principal position. She had made it quite clear to the panel that it was going to be difficult for her to work under my leadership and that she preferred a male principal to a female one. This immediately sparked a feeling that this was more personal than professional. I began questioning my self-worth and it caused me to struggle to keep our relationship civil to a point where I felt that it would be in the best interest of the institution to call it quits. This was an extremely difficult time for me and my family."
Emma admitted "gender has definitely had an impact on my principalship more so than my race. Some of the male teachers took transfers to other institutions where males were principals and some of my female educators clearly indicated that they preferred a male principal to a female principal. I constantly find that most of my challenges are from female teachers, female parents and female governors."

When we asked the women how they remained focused when encountering obstacles and discrimination, Matilda believed that "ignoring negative feelings is not healthy, nor is it wallowing in them. If life has handed me a tough hand, the only thing I may still have control over is my attitude. I try to maintain a positive attitude at all times. My strong faith gets me through most of my obstacles. My greatest obstacle was to become a principal in an African school; to work with a community who had about five different kinds of languages; [and] to be a coloured principal at a school with an African staff. I overcame all these obstacles by winning their trust and showing how much I care about the school community. Further to this, when asked about her overall experience as a principal in South Africa, Matilda lauded "the Gauteng Department of Education [for] consistently [being] supportive and helpful during my appointment. In aspiring to become a principal, women face a number of barriers including the traditional stereotyping. Sexism is a common experience after appointment. Research has found that men and women do not lead and manage in completely the same way."

Emma agreed that the principalship "is a very challenging position to be in. People are always surprised when they hear that you are a principal and the first words that come out are: 'it's good to see a female is in this position because it is a male dominated territory.' It seems that being a female principal in South Africa, you possess some kind of bravado/defiance; and once again the issues of culture and belief systems come into play. My personal take on this is that female teachers take offense to having a female principal and they tend to turn it into a personal issue which makes managing them so challenging especially in the primary schools”.

Upon hearing about the women's challenges, we were interested in what competencies they perceived were most critical to their survival and success as female principals. Matilda stressed that "being fair and honest; knowledgeable; knowing how to handle diversity; "support[ing] leaders in the school; strengthen[ing] school-family-community; develop[ing] [community] networks [e.g.] (local health and social service agencies)."Candice believed that "you have to be hard working; be on top of things; work ten times harder than your male counterpart; become hard core; put in long hours; want to succeed; and to prove everybody wrong [about women's leadership]." Emma decided "not [to] take anything personally. The ability to be accommodating, fair and transparent has allowed me to survive BUT most of all I refuse to compromise my principles as an individual." She continued by saying "I believed that a leader leads by example and supports those being lead. I was very naive in believing that everybody was on a certain level of maturity, [where] everybody likes me and that people will always be happy for you and support you as their leader." She soon 
realised the reality of principalship by stating that "not all your subjects are supportive of you. It's more difficult working with adults than with children. Not all people are mature even if they are adults. You will always be challenged irrespective of your motives." As a result she continued by saying, "I've decided not to trust anyone, to count my words when I speak, to listen more than I speak, [and] not to make decisions based on emotion.

When we asked the women if they planned on remaining a principal, all the women stated that they planned to resign. Matilda did not anticipate remaining a principal. She said, "No, I will not stay in this position as principal for too long. It can be very stressful and cumbersome at times. Parents, teachers and the district can be very demanding. I would love to work later in a less stressful environment." When asked about the future of women in leadership in South Africa she said: "I believe there is great hope for a better future with woman in the driver seat. Women are really great decision makers. A school of thought believes that women are better managers compared to their male counterparts. The opinion is that women are better at getting results because they have management style that tend to be participatory and interactive as opposed to men's command and control style. Women are nurturers and value-driven. They put feminine tough in all they do. "Emma also did not plan on remaining a principal: "No I do not want to remain in a principal position. I want to experience other areas that education has to offer. I don't think I'll venture into a different profession I enjoy education." Her thoughts about the future of women in South Africa were that "it does not matter what any authority/institution/government does to promote women it's going to take time for people to embrace this phenomena. People's upbringing, their belief systems and most importantly their cultures always seems to dictate on how they should respond." Finally, Candice also planned to resign.

\section{Discussion}

This article focused on three female principals and the impact of their intersecting identities of race, class and gender with sub-intersections of the impact of their professional and personal social networks and discrimination in their workplace. As other scholars [9,12], we believe that race, class and gender intersect within a context. In other words, we cannot thoroughly understand the problems of racism or sexism if we consider them as separate categories since we must be able to understand race in the context of gender and vice versa. By locating intersection as the center of analysis, this positioning allows us to view the multidimensional experiences of women and their resulting worldview. That is why we chose to examine the impact of the women's leadership experiences within the contexts of social networks that include family and community, and also the context of discrimination and stereotyping. All of these contexts inform the women's self-identity and their perception of opportunity as well as how they choose to engage in individual agency. In fact, we observe in this paper the three women 'acting,' 'performing' and mobilizing as women of colour in different ways [13].

In order to understand the obstacles and oppression that these women experienced, it is necessary to situate their experiences within the oppression of the historical, political, economic and cultural context that plays a central role in the legislation of South Africa and the lives of these women. More specifically, we examined more closely their experience as leaders within their schools, the impact of social networks on their self-esteem, and positive or negative support professionally and family/community support; and, the discrimination they faced. As leaders, all three women were extremely qualified as teachers. Two of the women actively sought out the principalship, and did not underestimate their qualifications nor their ambitions despite being discriminated against by both male and female colleagues. Interestingly, each woman (Matilda, Emma) hailed from different SES. It appears that the foundation of strong family support, community and religion served Matilda well as she entered the profession with much determination and confidence. For example, Matilda described herself as a 'born leader.' Despite feeling disenchanted with the principalship, Candice proudly shared the fact that she "was the first [and youngest] nonwhite person appointed in the South of Johannesburg at a former Model C school; and Emma stated that she always set promotional goals for herself and successfully achieved these goals with the culmination of the principalship. These feelings of pride were significant since female principals in schools remain rare and the women in our study illustrate a determination to challenge oppression and domination.

When the women encountered obstacles that seemed unique to their gender and ethnicity, their coping mechanisms included: being on top of things; working ten times harder than their male counterparts; becoming hard core; putting in long hours; being ambitious; proving everybody wrong; aligning with sympathetic male teachers; avoiding militant white teachers who felt threatened; not taking things personally; being accommodating, fair and transparent; and having strong faith. Nevertheless, all the women planned to resign.

The women's own perceptions before and after becoming principals turned out to be different. The reality proved to be more challenging than the women anticipated when having to deal with: negativity amongst their staff; a lack of professionalism and maturity; a realization that not all of their staff liked or trusted them; negative comments, discrimination, and backstabbing. Gupton and Slick [20] urge women not to reinforce the glass ceiling by not believing in themselves, and their potential to do well in leadership positions.

Women are too often perceived as incapable of leading educational institutions. These perceptions degrade women and contribute to them having to continuously prove themselves as effective leaders. Black and coloured women need to overcome gender differences by challenging patriarchal dominance and obstacles. This at times leads to emotional turmoil and doubting their selfworth. Despite the discriminatory remarks and prejudices, the women in our study managed to forge ahead with their own visions of their schools. The women continued to work responsibly and productively within unequal power structures [15]. This meant working at times in concert with the gender laws and customs. De Jong [15] calls this 'constructive complicity'. Bhabha [2] might call this 'collusion', that is, appearing to be submissive to the 
cultural gender laws with the system and yet subverting it by continuing their own daily work.

In our analysis of the data, the women experienced tension between being an agent of change (as female leaders) and being a bureaucrat (working alongside their black female and male colleagues as well as white females). De Jong [15] calls this, 'going into the belly of the beast', that is, becoming part of the beast as well as functioning according to, or colluding with, the logic of the beast, when expedient. What is critical is that the women worked through the potential paralysing effect this tension caused. They revealed that they were able to responsibly and productively, negotiate these differences without overtly challenging the status quo but rather by using peaceful, challenging measures. The women had varying developed identities as leaders, yet they all worked doggedly to negotiate gender and race binaries. Waiting, listening and working together were important strategies used by the women. They found hope in small transformations and successes. They did not engage in conflict. Sometimes, however, their own feelings of insecurity impacted their (in)ability to deal with conflict.

It is clear that patriarchy in schools is prevalent, particularly in schools with black or coloured female principals as the women dealt with resistance, insubordination and sabotage [19]. Discriminatory views often stereotype women as being incapable and emotionally unstable. Women are encouraged to challenge these societal patterns and change the status quo by applying for senior positions [22]. Pigford and Tonnsen [28] posit that women often underestimate their performances, while men overestimate theirs. In other words, women's successes are often attributed to luck or hard work, whereas the successes men achieve are attributed to innate ability. Despite contradictory evidence, stereotypes concerning female inadequacy as leaders persist and act to distort perceptions of male and female performance and potential. One obvious consequence of these perceptions is that a man is more likely to be selected for a leadership position over an equally qualified female because gender role stereotypes and cultural beliefs such as those mentioned in this paper have evolved from traditional roles that women have played for years. Although education appears to be undergoing a feminisation of leadership both demographically and conceptually in South Africa, our study, while not generalisable, reveals that black and coloured women still encounter barriers in their role as principal.

According to the Department of Education [16], South African society is still very patriarchal and discriminatory. Women are still viewed as second-class citizens, subservient to men, as mothers and homemakers. Racial minorities are constantly negotiating the intersections of race, class, discrimination, and oppression. Gaganakis [18] describes some of the more salient inhibiters of female success that includes male bias in textbooks and in extracurricular activities; men's dominance of authority positions; sexual harassment; and what he calls, "gender panic". Heillustrates this phenomenon as a girl, adolescent or woman's fear of being shunned by men if they are too clever; and a loss of confidence in their ability to succeed. Stereotypes emanate from the belief system of South African culture, privilege, power, and patriarchy creating inequalities between men and women [18]. In this way, social history is retold through gendered intersections of gender and race. Gender, a narrative of domination, shapes every moment of life. For individuals who do not conform or present socially scripted representations of patriarchal norms are called into question. In this way, the role of principal and the school as an institution develop out of hegemonic discourse, becomes less available or attainable as protection from gender and racial marginalisation, torment, and abuse. Intersectionality is a powerful tool of analysis because it can account for interactions of class, race and gender within a context of dominant and oppressive influence.

\section{Conclusion}

These three stories of principals' experiences in South Africa contribute to the rare stories that juxtapose the silence in mainstream media. Until we acknowledge and reconcile the damage done through patriarchal oppression and domination, intersectionality theory utilises indigenous epistemologies and worldviews in their great diversity, and recognises the relationships between humans and all of nature as equal and important sources of knowing. These women and their actions in the face of discrimination and leadership responsibilities as coloured women are essential examples of fortitude and courage. By heightening the awareness of the women's experiences, the findings can inform policy development and processes that resist oppressive images of South African women and provide solutions rooted in the community and tradition while recognizing the complexity and diversity of these communities. Through examples and stories like those in this paper, scholars can move forward from, and beyond, the legacy of policies that create harm towards those that have the potential for transformation and equity.

\section{Recommendations}

1. Professional learning communities (also referred to as a community of practice, a focus group or a special interest group) are proposed, where women leaders come together to explore their aspirations, ambitions, and challenges. Technological platforms, training, and tools that enable Professional Learning Communities of female principals. Women discuss ways to reach out to others, confronting their own professional challenges in the labyrinth of leadership. The goal of these efforts would be to provide support for women in moving beyond the narrow band of leadership. This recommendation is very similar to Cooperative Inquiry ("CI"), defined in the literature as a "systematic process of action and reflection among co-inquirers who are tackling a common concern of burning interest." CI "gives equal value to learning and research in the service of action, giving primacy to practice as a source of knowing."

2. NGOs as part of their social responsibility are required to invest in public schools. Although research indicates that $49 \%$ of all social investment expenditure was allocated to education in 2014, very little is apportioned to help develop women to take on leadership positions [31]. The NGO sector can play a significant, targeted role in education, if it adheres to evidence-based, 
empirically-proven interventions in teaching and leading schools, as it is from this platform of school leadership that reform efforts are undertaken. Some support includes:

- identifying coping mechanisms of women principals in terms of their journey to principalship, and to make recommendations about cultivating their problem-solving skills;

- making recommendations about management skills acquisition (in the form of leadership training and professional development) going forward, particularly for NGO interventions;

- refresher workshops on finance, school discipline, curriculum management, conflict management are topics that women school leaders require training and development;

- Mentoring programmes for women and peer support groups

Kindly note:

The Bill of Rights as entrenched in the South African Constitution provides for gender equality and the Employment Equity Act, No 55 of 1998 aims to achieve equity in the workplace by promoting equal opportunity and fair treatment in employment through elimination of unfair discrimination and implementing affirmative action measures to redress the disadvantages in employment experienced by designated groups, in order to ensure equitable representation in all occupational categories and levels in the workforce.

At school level it is difficult to implement both, the Equity Act and the Constitution. The process of promotion is as follows: Teachers may apply to promotion posts of heads of departments, deputy principals and principals as advertised by the provincial department of education gazette. The governing bodies receives all the applications and shortlist the candidates based on criteria developed by these governing bodies and interview the shortlisted candidates. Since democratic values underpin the process, females are not given any preferences. Also, based on the needs of each individual, professional development programmes are designed and implemented accordingly. Thus, even though policies may suggest equity, women will not be given any preferences at school level.

At community level, it is also difficult to get communities to make a paradigm shift. Most communities, especially the coloureds, Indians and blacks still treat women inferior to men.

\section{References}

[1] Adhirkari M 2004. Hope, fear, shame, frustration: Continuity and change in the expression of Coloured identity in White a supremacist South Africa. Journal of Southern African Studies, 32 (3): 467-486.

[2] Bhabha H 1995. Cultural diversity and cultural differences. In B Ashcroft, G Griffiths \& H Tiffin (eds).The post-colonial studies reader. New York: Routledge.

[3] Blackmore J, Thomson P \& Barty K 2006. Principal selection: Homosociability, the search for security and the production of normalized principal identities. Educational Management Administration \& Leadership, 34 (3): 297-315.

[4] Bourdieu P 1986. The Forms of Capital. In J.G. Richardson (ed.), Handbook oftheory and research for the sociology of education. New York: Greenwood Press.
[5] Chanee A 2014. Personal interview on Gauteng Department of Education (GDE) statistics. Johannesburg: GDE office.

[6] Charmin K 2003. Grounded theory: Objectivist and constructivist methods In NK Denzin\& YS Lincoln (eds.), Strategies for qualitative inquiry. Thousand Oaks: Sage.

[7] Clark J 2012. Mother power in the African context: Resisting agendas through mobilizing $\mathrm{m} /$ other positions. Radical Psychology, 9 (2).Available at

http://www.radicalpsychology.org/vol9-2/clark.html. Retrieved 27 April 2013.

[8] Collins PH 1998. Fighting words: Black women and the search for justice. Minneapolis: University of Minnesota Press.

[9] Collins PH 2000. Black feminist thought: Knowledge, consciousness, and the politics of empowerment. New York: Routledge.

[10] Cotter AM 2004. Gender injustice: An international comparative analysis of equality inemployment. Burlington, VA: Ashgate.

[11] Creswell JW 2003. Research design: Qualitative and quantitative approaches and mixed methods approaches. London: Sage.

[12] Crenshaw K 1989. Demarginalizing the intersection of race and sex: A Black feminist critique of antidiscrimination doctrine, feminist theory, and antiracist politics. The University of Chicago Legal Forum, 140:139-167.

[13] Crenshaw K 1991. Mapping the margins: Intersectionality, identity politics, and violence against women of color. Stanford Law Review, 43: 1241-1299.

[14] Cubillo L \& Brown M 2003. Women into educational leadership and management: International differences? Journal of Educational Administration, 41: 278-91.

[15] De Jong S 2009. Constructive complicity enacted? The reflections of women NGO and IGOworkers on their practices. Journal of Intercultural Studies, 30: 387-402.

[16] Department of Education 1997. White Paper on Integrated National Disability Strategy. Availaible at http://polity.org.za/govdocs/white_papers/disability1.htm. (Accessed, 13 February 2014).

[17] Department of Education 2006. Statistical overview survey. Ordinary and special education in Gauteng. Johannesburg: Gauteng Department of Education.

[18] Geldenhuys J \& de Lange N 2007. Career identities of first year female coloured students. South African Education, 27 (1): 117137.

[19] Greyvenstein LA 2000. The untapped human resource? An overview of women in educational management in South Africa. South African Journal of Education, 20: 30-3.

[20] Gupton SL \& Slick GA 1996. Highly successful women administrators: The inside stories of how they got there. Thousand Oaks, CA: Corwin Press.

[21] Hooks b 1994. Outlaw culture. New York, Routledge.

[22] Ledwith S \&Colgan F 1996. Women in organizations: Challenges in gender politics. London: Macmillan.

[23] Lincoln YS \&Guba EG 1995. Naturalistic inquiry. London: Sage.

[24] Mahlase S 1997. The careers of women teachers under Apartheid. Harare: SAPES Books.

[25] Mestry R \& Schmidt M 2012. A feminist postcolonial examination of female principals' experiences in South African secondary schools. Gender and Education, 24 (5): 535-551.

[26] Moorosi P 2008. Creating linkages between private and public: Challenges facing women principals in South Africa. South African Journal of Education, 27(3): 507-521.

[27] Naidoo J 2004. Educational decentralization and school governance: from policy to practice. M Ed. Dissertation. Harvard: Harvard Graduate School of Education.

[28] Pigford AB \& Tonnsen A 1993. Women in school leadership: Survival and advancement guide book. Washington, DC: Technomic Publishing Company.

[29] Shenton AK 2004. Strategies for ensuring trustworthiness in qualitative research projects. Education for Information, 22: 63-7.

[30] South Africa 1996. The Constitution of the Republic of South Africa, No. 108 of 1996. Pretoria: Government Printers.

[31] Trailogue (2014). The Trialogue 2014 CSI Handbook, $17^{\text {th }}$ Edition. Cape Town: Trialogue Publishing. 